\title{
Reinforcement of Lignin-Based Phenol-Formaldehyde Adhesive with Nano-Crystalline Cellulose (NCC): Curing Behavior and Bonding Property of Plywood
}

\author{
Zhenbo Liu ${ }^{1,2}$, Yaolin Zhang2 ${ }^{*}$, Xiangming Wang2*, Denis Rodrigue ${ }^{3}$ \\ ${ }^{1}$ Key Laboratory of Bio-Based Material Science and Technology (Ministry of Education) \& Northeast Forestry \\ University, Harbin, China \\ ${ }^{2}$ FPInnovations-Wood Products, Quebec, Canada \\ ${ }^{3}$ Department of Chemical Engineering, Laval University, Quebec, Canada

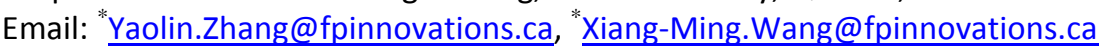

Received 10 December 2014; accepted 23 June 2015; published 26 June 2015

Copyright $@ 2015$ by authors and Scientific Research Publishing Inc.

This work is licensed under the Creative Commons Attribution International License (CC BY). http://creativecommons.org/licenses/by/4.0/

(c) $\underset{\mathrm{EY}}{\mathrm{EY}}$ Open Access

\section{Abstract}

The curing behavior of lignin-based phenol-formaldehyde (LPF) resin with different contents of nano-crystalline cellulose (NCC) was studied by differential scanning calorimetry (DSC) at different heating rates $\left(5,10\right.$ and $\left.20^{\circ} \mathrm{C} / \mathrm{min}\right)$ and the bonding property was evaluated by the wet shear strength and wood failure of two-ply plywood panels after soaking in water (48 hours at room temperature and followed by 1-hour boiling). The test results indicated that the NCC content had little influence on the peak temperature, activation energy and the total heat of reaction of LPF resin at 5 and $10^{\circ} \mathrm{C} / \mathrm{min}$. But at $20^{\circ} \mathrm{C} / \mathrm{min}$, LPF0.00\% (LPF resin without NCC) showed the highest total heat of reaction, while LPF0.25\% (LPF resin containing $0.25 \%$ NCC content) and LPF0.50\% (LPF resin containing $0.50 \%$ NCC content) gave the lowest value. The wet shear strength was affected by the NCC content to a certain extent. With regard to the results of one-way analysis of variance, the bonding quality could be improved by NCC and the optimum NCC content ranged from $0.25 \%$ to $0.50 \%$. The wood failure was also affected by the NCC content, but the trend with respect to NCC content was not clear.

\section{Keywords}

Lignin-Based Phenol-Formaldehyde Resin (LPF), Nano-Crystalline Cellulose (NCC), Curing Behavior, Bonding Properties, Plywood

\footnotetext{
${ }^{*}$ Corresponding authors.

How to cite this paper: Liu, Z.B., Zhang, Y.L., Wang, X.M. and Rodrigue, D. (2015) Reinforcement of Lignin-Based Phenol-Formaldehyde Adhesive with Nano-Crystalline Cellulose (NCC): Curing Behavior and Bonding Property of Plywood. Materials Sciences and Applications, 6, 567-575. http://dx.doi.org/10.4236/msa.2015.66060
} 


\section{Introduction}

Lignin is one of the three main components of wood, and its content in hardwoods is usually in the range of 18 to $25 \%$, whereas it varies between $25 \%$ and $35 \%$ in softwoods [1]. Lignin is a biopolymer composed of phenylpropane $\left(\mathrm{C}_{9}\right)$ as a basic structural unit, which is connected by carbon-carbon and ether (R-O-R) bonds forming a high-molecular-weight and a three-dimensional highly branched network with a variety of functional groups [2]. Because lignin contains phenolic compounds, it has been used to partially substitute phenol in the manufacturing of phenol-formaldehyde resins for wood composites products. Because of the low reactivity of lignin with formaldehyde, several researchers tried to replace phenol with lignin for phenolic resin development in past few decades, but have not reached commercial applications yet. To produce more reactive phenolic precursors, lignin can be modified prior to resin synthesis. Lignin-based phenolic resins were synthesized and investigated using various percentages of lignin replacement for phenol. Then, the bonding property was evaluated through mechanical testing of oriented strandboard (OSB) or plywood manufactured with lignin-based phenolic resins [3]-[18].

Cellulose, the main component of the cell walls of trees and other plants, is the most abundant material in the biosphere, and a long-chain polysaccharide composed of $\beta$-1,4-linked D-glucose rings [19]. In its almost-pure form, cellulose has a crystalline molecular structure. Known as nano-crystalline cellulose or NCC, this substance has intriguing properties and uses. Nano-crystalline cellulose is obtained by the acid hydrolysis of cellulose under conditions where the amorphous regions are selectively hydrolyzed [20] [21]. The tensile modulus along the length of these NCC can reach 145 GPa, which is higher than that of $\operatorname{Kevlar}{ }^{\circledR}$ (130 GPa) [22] [23]. NCC has a high aspect ratio, low density and a reactive surface that facilitates grafting chemical species to achieve different surface properties (surface functionalization) [20] [24]. These features are favorable for NCC use as a reinforcing component in building materials to increase their mechanical strength, stiffness, toughness, thermal stability and durability [25]-[33]. Because of such advantages, NCC could be added into lignin-based phenol- formaldehyde adhesive (LPF) for improving bonding properties. But the literature available on the effects of NCC on the curing behavior and the bonding properties of LPF is limited.

The purpose of this study was to add different amounts of nano-crystalline cellulose (NCC) into lignin-based phenol-formaldehyde (LPF) resins and investigate the effect of NCC addition and content on the curing behavior and bond quality of LPF resins. The curing behavior of the resins was characterized by differential scanning calorimetry (DSC) for the peak temperature and heat flow at different heating rates to get activation energies as well. Two-ply plywood panels were then prepared with the LPF resins containing different NCC contents and the effect of NCC on the properties of wood composites, in terms of lap-shear strength and wood failure, was evaluated under wet conditions.

\section{Materials and Methods}

\subsection{Preparation of Lignin-Based Phenol-Formaldehyde (LPF) Resins}

LPF resins were synthesized in the laboratory with formaldehyde to phenol molar ratio of $2.5,45 \%$ solid content (SC) and 33\% phenol replacement with lignin donated by Tembec (Canada). Sodium hydroxide (NaOH), was used as a catalyst. The reactions were in two steps: 1) methylolation of phenol and lignin with formaldehyde at low temperature (around $70^{\circ} \mathrm{C}$ for certain period of time), 2) condensation at higher temperature (over $80^{\circ} \mathrm{C}$ ). The viscosity of the resin was monitored and the reaction was terminated when the viscosity reached 150 to 200 cps. Viscosities were measured by a Brookfield viscometer from Brookfield Engineering Laboratories (Middleboro, MA). The resulting adhesives was then stored at $4^{\circ} \mathrm{C}$ and $80 \%$ relative humidity until used.

The resin was then divided into 6 parts and the NCC, provided by FPInnovations-Pulp \& Paper Division, was added with $0,0.1,0.25,0.5,1.0$ and $1.5 \%$ content based on the liquid weight of the LPF resin, which corresponds to resin solid contents of: $0,0.22,0.56,1.11,2.22$ and $3.33 \%$ wt These resins were labeled as the NCC content: LPF $0.00 \%$, LPF $0.10 \%$, LPF $0.25 \%$, LPF $0.50 \%$, LPF $1.00 \%$ and LPF $1.50 \%$, respectively. Then, all the resins were stirred with a high speed mixer (Brook Crompton, Ragogna Custom Machinery LTD) at a rotating speed of $5000 \mathrm{rpm}$ for $30 \mathrm{~min}$ to obtain homogeneous mixtures.

\subsection{Differential Scanning Calorimetry (DSC) Measurements}

All DSC measurements were conducted with a TA DSC 2910 from TA Instruments. About 5 mg of adhesive 
sample was placed in an aluminum pan and sealed. The sealed aluminum pan was then placed in a heating chamber and a pressure of $4000 \mathrm{kPa}$ was applied. Heating rates of 5,10 and $20^{\circ} \mathrm{C} / \mathrm{min}$ were used and the scanning temperature ranged from $25^{\circ} \mathrm{C}$ to $250^{\circ} \mathrm{C}$ under a nitrogen atmosphere. For each heating rate, two replicates were performed. The data were analyzed with the Universal Analysis software (TA Instruments).

Based on the DSC curves, the activation energy and total heat of reaction were analyzed in this study. The activation energy involved in the curing process was evaluated by Ozawa method and Kissinger method from the peak temperatures of the DSC scans at three different heating rates [34]-[36]. The Ozawa method is based on a linear relationship between the logarithm of the resin heating rate and the inverse of the peak temperature as follows [35]:

$$
\log \beta=-0.4567 \frac{E_{a}}{R T_{p}}-2.315+\log \left(\frac{Z E_{a}}{R}\right)-\log F(\alpha)
$$

where, $\beta$ is the heating rate $\left({ }^{\circ} \mathrm{C} / \mathrm{min}\right), E_{\mathrm{a}}$ is the activation energy $(\mathrm{J} / \mathrm{mol}), R$ is the gas constant $(8.314 \mathrm{~J} / \mathrm{mol} \cdot \mathrm{K})$, $T_{\mathrm{p}}$ is the peak temperature $(\mathrm{K}), Z$ is the pre-exponential factor of the curing kinetics, and $F(\alpha)$ is a function related to the conversion rate, but independent of $\beta$ and $T_{\mathrm{p}}$.

The Kissinger method is similar to Ozawa. It relates the logarithm of $\left(\beta / T_{p}^{2}\right)$ with the inverse of the peak temperature $\left(T_{p}\right)$ as follows [34]:

$$
-\ln \frac{\beta}{T_{p}^{2}}=\frac{E_{a}}{R T_{p}}-\ln \left(\frac{Z R}{E_{a}}\right)
$$

In order to better compare between different LPF resins, the total heat of reaction was evaluated from $60^{\circ} \mathrm{C}$ to $200^{\circ} \mathrm{C}$ based on the DSC curves.

\subsection{Preparation of Two-Ply Plywood Panels}

Peeled yellow birch veneers with dimensions of 310 by 135 by $1.5 \mathrm{~mm}$ (length by width by thickness) were used in this study. The veneers were initially stored at $20^{\circ} \mathrm{C}$ and $20 \%$ relative humidity (RH). The "tight" sides of the veneers were chosen for gluing. The resin spread rate was $-80 \mathrm{~g} / \mathrm{m}^{2}$ at a solid resin basis, which means that around $178 \mathrm{~g}$ of liquid resin (45\% solid content) will be applied to one "tight" side of veneer to assemble two ply. The assembled panels were pressed in a steam heated press (Vickers Incorporated Troy, Michigan U.S.A.) at $150^{\circ} \mathrm{C}$ and $340 \mathrm{psi}$ for $5 \mathrm{~min}$ and two replicate panels were manufactured for each resin. Then, the plywood panels were stored at $20^{\circ} \mathrm{C}$ and $50 \% \mathrm{RH}$ for at least 10 days prior to cutting. The lap-shear strength specimens were cut from plywood panels with dimensions of 12.5 by $70 \mathrm{~mm}$ (width by length), as shown in Figure 1. Great care in producing the specimens was taken to ensure that the cutting saw extended to, but not went beyond the bond-line. Two wet conditions were used in the lap-shear strength test: 1) soaking in water at room temperature for 48 hours and 2) boiling in water for 1 hour. After that, the specimens were tested while still wet at room temperature. Shear strength was measured using an Instron Model 1000 (Norwood, Massachusetts) with a loading rate of $1500 \mathrm{~N} / \mathrm{min}$. For each testing condition, 30 specimens were prepared and measured.

\subsection{Data Analysis}

Tukey’s test was applied, which is also known as Tukey’s HSD (Honestly Significant Difference) test [37] or

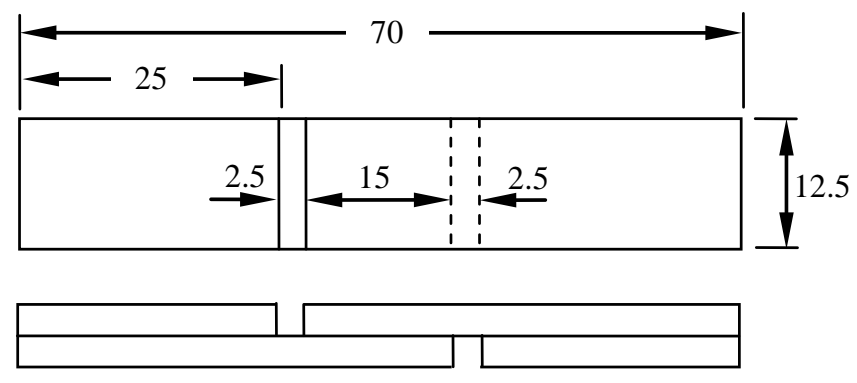

Note: All dimensions given are in millimeters.

Figure 1. Geometry and dimensions of the lap-shear specimens. 
the Tukey-Kramer method. It is a single-step multiple comparison procedure and the statistical test is generally used in conjunction with an ANOVA to find which parameters are significantly different from one another. Named after John Tukey, it compares all possible pairs of means. It is based on a studentized range distribution $q$ (distribution similar to the $t$ distribution from the $t$-test).

\section{Result and Discussion}

\subsection{NCC Content and Viscosity}

The viscosity results are presented in Table 1 . The viscosity of LPF resin without NCC was 340 cps. Table 1 shows that the viscosity increases slowly with increasing NCC content in the range of $0 \%$ to $1.0 \%$, but increases more importantly with further increasing NCC content. The highest resin viscosity was $4050 \mathrm{cps}$, which was observed for LPF $1.50 \%$.

\subsection{Curing Behavior and Kinetic Analysis}

DSC curves with three heating rates $\left(5,10\right.$ and $\left.20^{\circ} \mathrm{C} / \mathrm{min}\right)$ for LPF resins containing different NCC contents are presented in Figures 2-4, respectively. Figure 3 and Figure 4 show that DSC curves for all resins have only one

Table 1. Viscosity of LPF resins with different NCC contents.

\begin{tabular}{cccc}
\hline \multirow{2}{*}{ Sample } & \multicolumn{2}{c}{ NCC Content (\%) } & Viscosity (cps) \\
\cline { 2 - 3 } & Based on liquid & Based on SC & 340 \\
LPF0.00\% & 0.00 & 0.00 & 870 \\
LPF0.10\% & 0.10 & 0.22 & 1160 \\
LPF0.25\% & 0.25 & 0.56 & 1370 \\
LPF0.50\% & 0.50 & 1.11 & 1870 \\
LPF1.00\% & 1.00 & 2.50 & 4050 \\
LPF1.50\% & 1.50 & 3.33 & \\
\hline
\end{tabular}

SC: non-volatile content in phenolic resin.

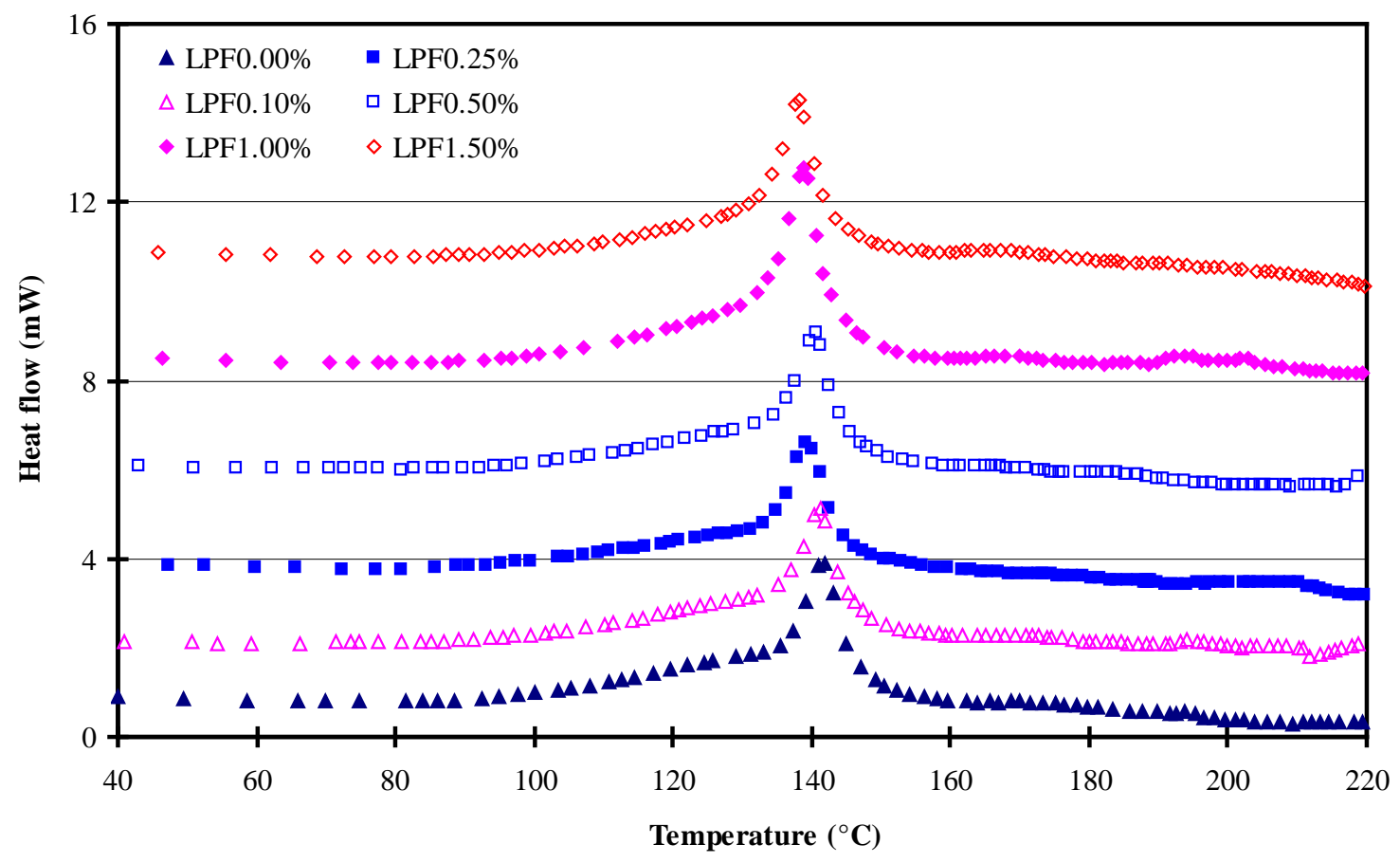

Figure 2. DSC curves of lignin-based phenolic resins with different NCC contents scanned at $5^{\circ} \mathrm{C} / \mathrm{min}$. 


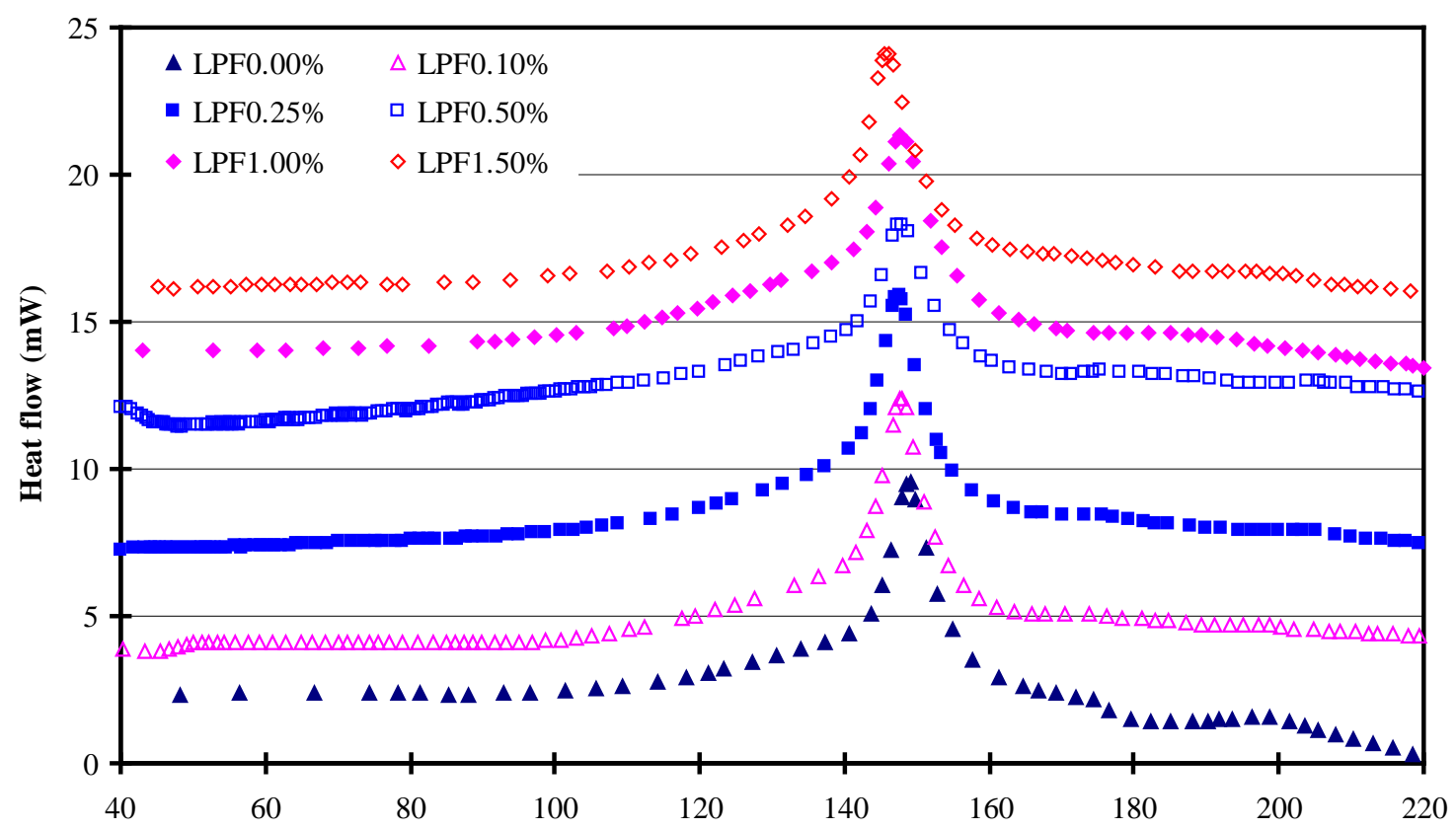

Temperature $\left({ }^{\circ} \mathrm{C}\right)$

Figure 3. DSC curves of lignin-based phenolic resins with different NCC contents scanned at $10^{\circ} \mathrm{C} / \mathrm{min}$.

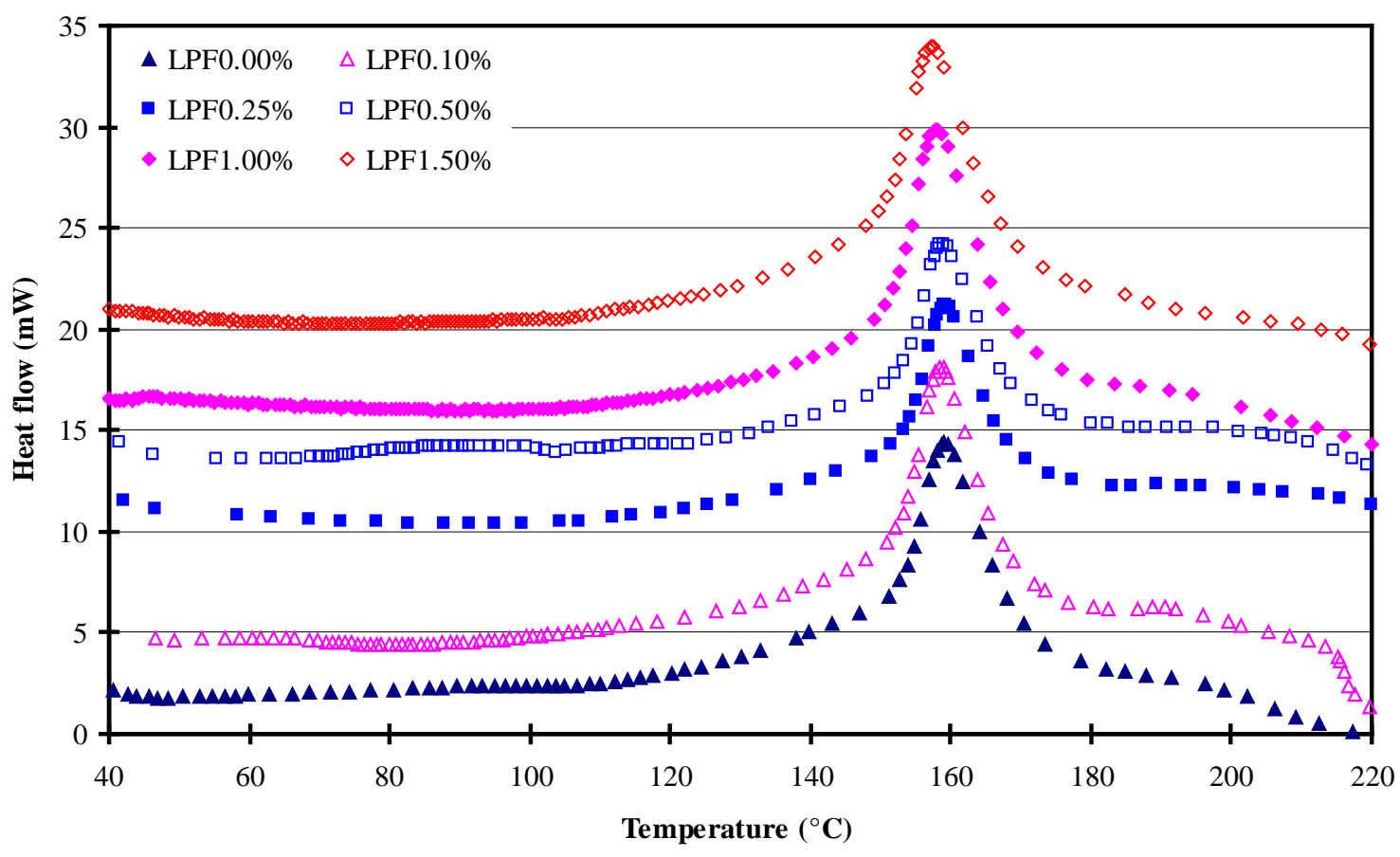

Figure 4. DSC curves of lignin-based phenolic resins with different NCC contents scanned at $20^{\circ} \mathrm{C} / \mathrm{min}$.

peak, and the peak temperatures of all resins are similar. The peak temperatures shown in Table 2 were in the ranges of $138.8^{\circ} \mathrm{C}-140.5^{\circ} \mathrm{C}, 146.5^{\circ} \mathrm{C}-150.2^{\circ} \mathrm{C}$ and $157.7^{\circ} \mathrm{C}-159.3^{\circ} \mathrm{C}$ for the heating rates of $5^{\circ} \mathrm{C}, 10^{\circ} \mathrm{C}$ and $20^{\circ} \mathrm{C} / \mathrm{min}$, respectively. The DSC curve shapes of all resins are also similar. This may indicate that there was no reaction between NCC and LPF resin.

In this study, the activation energy of the curing process was evaluated by the methods of Ozawa and Kissinger. The activation energies of the resin curing and regression coefficients $\left(r^{2}\right)$ for different NCC contents are 
shown in Table 2.

Both methods were consistent with each other. The activation energies varied between 92 and $112 \mathrm{~kJ} / \mathrm{mol}$ and changed slightly among all resins with different NCC contents. Comparison with the $\mathrm{E}_{\mathrm{a}}$ value of the control resin (without NCC addition), the variations of $\mathrm{E}_{\mathrm{a}}$ are from the lower end $-9.2 \%$ (Kissinger method) or $-8.6 \%$ (Ozawa method) for the LPF resin with 1.5\% NCC, to the higher end 8.9\% (Kissinger method) or 8.4\% (Ozawa method) for the LPF resin with $0.5 \%$ NCC. This indicates that the addition of NCC to lignin based phenolic resin does not have a significant impact on the activated energy of the curing reaction of lignin based phenolic resin. The total heat of reaction of PF curing was also calculated and the results are shown in Table 2 . The variation of $\Delta \mathrm{H}$ between resins with and without NCC are $-4.2 \%$ to $3.4 \%$ at a heating rate of $5{ }^{\circ} \mathrm{C} / \mathrm{min},-5.5 \%$ to $13.7 \%$ at a heating rate of $10^{\circ} \mathrm{C} / \mathrm{min}$, and $-20.5 \%$ to $-10.9 \%$ at a heating rate of $20^{\circ} \mathrm{C} / \mathrm{min}$. At the highest heating rate $\left(20^{\circ} \mathrm{C} / \mathrm{min}\right)$, it is possible that NCC might absorb some reaction energy to heat up which resulted in lower $\Delta \mathrm{H}$. Based on the $\mathrm{E}_{\mathrm{a}}$ and $\triangle \mathrm{H}$ of LPF with and without NCC, it can be seen that NCC addition does not significantly affect the curing behavior of lignin based phenolic resin.

\subsection{Plywood Properties}

Wet shear strength and wood failure of plywood panels after 48 hours soaking in water at room temperature and after 1 hour in boiling water were evaluated in this study. Wood failure is usually expressed as a percentage of the total bonding area. The results are shown in Table 3.

Table 3 shows that the wet shear strength is affected by NCC content to a certain extent. The shear strength increases with increasing NCC content in the range of $0 \%$ to $0.25 \%$, and decreases in the range of $0.25 \%$ to $1.5 \%$. With Tukey group analysis, the lap-shear strength is in same group for plywood bonded with LPF adhesive with NCC content between $0.25 \%$ and $0.50 \%$, which is equivalent to adding $0.56 \%-1.11 \%$ NCC based on resin solid content. Further increase of NCC content decreased the strength. Since the surface area of NCC is quite high and the lignin based phenolic resin may not cover the whole surface area, it is difficult to prevent NCC particles contacting each other after curing when the NCC loading is higher than $0.5 \%$ (1.11\% SC). If NCC aggregates are present, this will definitely reduce the bonding strength with the resin. This may explain why the strength

Table 2. DSC results of LPF with different NCC contents.

\begin{tabular}{|c|c|c|c|c|c|c|c|c|c|c|}
\hline \multirow{2}{*}{ Samples } & \multicolumn{3}{|c|}{$T_{p}\left({ }^{\circ} \mathrm{C}\right)$} & \multicolumn{2}{|c|}{ Kissinger Method } & \multicolumn{2}{|c|}{ Ozawa Method } & \multicolumn{3}{|c|}{ Heat of Reaction $(\mathrm{J} / \mathrm{g})^{*}$} \\
\hline & $5^{\circ} \mathrm{C} / \mathrm{min}$ & $10^{\circ} \mathrm{C} / \mathrm{min}$ & $20^{\circ} \mathrm{C} / \mathrm{min}$ & $E_{\mathrm{ak}}(\mathrm{kJ} / \mathrm{mol})$ & $r^{2}$ & $E_{\text {ao }}(\mathrm{kJ} / \mathrm{mol})$ & $r^{2}$ & $5^{\circ} \mathrm{C} / \mathrm{min}$ & $10^{\circ} \mathrm{C} / \mathrm{min}$ & $20^{\circ} \mathrm{C} / \mathrm{min}$ \\
\hline LPF0.00\% & 140.2 & 150.2 & 159.2 & 101.7 & 0.998 & 103.4 & 0.998 & 115.2 & 139.4 & 143.4 \\
\hline LPF0.10\% & 140.1 & 147.7 & 157.9 & 106.1 & 0.997 & 107.6 & 0.997 & 113.8 & 131.7 & 127.7 \\
\hline LPF0.25\% & 140.3 & 148.3 & 158.4 & 108.0 & 0.995 & 109.4 & 0.995 & 116.6 & 158.5 & 114.5 \\
\hline LPF0.50\% & 140.5 & 147.7 & 157.8 & 110.8 & 0.992 & 112.1 & 0.993 & 118.5 & 147.8 & 114.0 \\
\hline LPF1.00\% & 138.8 & 147.7 & 157.9 & 100.1 & 0.999 & 101.9 & 0.999 & 110.4 & 149.5 & 123.6 \\
\hline LPF1.50\% & 138.8 & 146.5 & 159.2 & 92.3 & 0.981 & 94.5 & 0.984 & 119.1 & 153.3 & 122.0 \\
\hline
\end{tabular}

${ }^{*}$ The heat of reaction was calculated based on the weight of liquid resin.

Table 3. Result of wet shear strength of plywood and wood failure.

\begin{tabular}{|c|c|c|c|c|c|c|c|c|}
\hline \multirow[b]{2}{*}{ Sample } & \multicolumn{4}{|c|}{ 48-hour Soaking } & \multicolumn{4}{|c|}{ 1-hour Boiling } \\
\hline & $\begin{array}{c}\text { Mean Strength } \\
(\mathrm{kPa})\end{array}$ & $\begin{array}{c}\text { Tukey } \\
\text { Grouping }\end{array}$ & $\begin{array}{l}\text { Wood Failure } \\
\text { (\%) }\end{array}$ & $\begin{array}{l}\text { Tukey } \\
\text { Grouping }\end{array}$ & $\begin{array}{c}\text { Mean Strength } \\
(\mathrm{kPa})\end{array}$ & $\begin{array}{l}\text { Tukey } \\
\text { Grouping* }\end{array}$ & $\begin{array}{c}\text { Wood Failure } \\
\text { (\%) }\end{array}$ & $\begin{array}{l}\text { Tukey } \\
\text { Grouping* }\end{array}$ \\
\hline LPF0.00\% & 5307 & $\mathrm{C}$ & 9 & $\mathrm{C}$ & 4948 & $\mathrm{C}$ & 8 & $\mathrm{D}$ \\
\hline LPF0.10\% & 5460 & B C & 57 & A B & 5280 & A B C & 52 & A B \\
\hline LPF0.25\% & 6057 & A & 47 & A B & 5625 & A & 41 & B C \\
\hline LPF0.50\% & 5777 & A B & 45 & $\mathrm{~B}$ & 5499 & A B & 47 & A B \\
\hline LPF1.00\% & 5348 & $\mathrm{C}$ & 40 & $\mathrm{~B}$ & 5102 & B C & 18 & C D \\
\hline LPF1.50\% & 5334 & $\mathrm{C}$ & 72 & A & 5163 & A B C & 69 & A \\
\hline
\end{tabular}

${ }^{*}$ At the 0.05 level. 
increased and then decreased with increasing NCC content.

Table 3 also shows that wood failure is affected by NCC content. The resin without NCC (LPF0.00\%) has the lowest wood failure and the one with 1.5\% NCC has the highest wood failure. However, the general trend of wood failure with NCC content is not clear due to high scatter. More work will be needed to explain this behavior which can again be related to NCC dispersion in the resin.

\section{Conclusions}

The curing behavior of lignin-based PF resin with different NCC contents was studied by a high-pressure DSC at heating rates of 5,10 and $20^{\circ} \mathrm{C} / \mathrm{min}$. Then, two-ply plywood panels were made and the wet shear strength was evaluated.

The results indicated that DSC curves for all resins had only one peak, and the values of the peak temperatures were close. The activation energy of the resin was less influenced by NCC addition, so was the total heat of reaction for the heating rates of $5^{\circ} \mathrm{C}$ and $10^{\circ} \mathrm{C} / \mathrm{min}$. On the other hand, at $20^{\circ} \mathrm{C} / \mathrm{min}$, LPF0.00\% had the highest total heat of reaction, while LPF0.25\% and LPF0.50\% had the lowest value. On the other hand, the wet shear strength was more affected by NCC content. The shear strength increased with increasing NCC content in the range between $0 \%$ and $0.25 \%$ and then decreased in the range of 0.25 to $1.5 \%$. Considering the results of the one-way analysis of variance, the bonding quality could be improved by adding NCC and the optimum NCC content was in the range of $0.25 \%$ to $0.5 \%$. The wood failure was also affected by the NCC content, but the general trend was not clear due to high scatter. As a general conclusion, the results indicated that the optimum NCC content for addition into lignin-based PF is between $0.25 \%$ and $0.50 \%$ with regard to improved bond quality of plywood panel.

\section{Acknowledgements}

The authors would like to acknowledge the financial support from the Project of Innovation and Introducing Intelligence Base of Forestry Engineering (Abbreviating “111” Project, B08016) of China. The assistance of Stephane Raymond, technologist at FPInnovations-Wood Products, in plywood panel preparation and testing, is also acknowledged

\section{References}

[1] Rowell, R.M. (2005) Wood Chemistry and Wood Composites. CRC Press, Boca Raton.

[2] Pizzi, A. (2003) Chap. 28. In: Pizzi, A., Ed., Handbook of Adhesive Technology, 2nd Edition, Marcel Dekker, New York.

[3] Campbell, A.G. and Walsh, A.R. (1985) The Present Status and Potential of Kraft Lignin-Phenol-Formaldehyde Wood Adhesives. Journal of Adhesion, 18, 301-314. http://dx.doi.org/10.1080/00218468508080465

[4] Wooten, A.L., Sellers Jr., T. and Tahir, P.M. (1988) Reaction of Formaldehyde with Lignin. Forest Products Journal, 38, 45-46.

[5] Olivares, M., Guzman, J.A., Natho, A. and Saavedra, A. (1988) Kraft Lignin Utilization in Adhesives. Wood Science and Technology, 22, 157-165. http://dx.doi.org/10.1007/BF00355851

[6] Klasnja, B. and Kopitovic, S. (1992) Lignin-Phenol-Formaldehyde Resins as Adhesives in the Production of Plywood. Holz als Roh- und Werkstoff, European Journal of Wood and Wood Products, 50, 282-285. http://dx.doi.org/10.1007/BF02615352

[7] Barry, A.O., Peng, W. and Riedl, B. (1993) The Effect of Lignin Content on the Cure Properties of Phenol-Formaldehyde Resin as Determined by Differential Scanning Calorimetry. Holzforschung, 47, 247-252. http://dx.doi.org/10.1515/hfsg.1993.47.3.247

[8] Doering, G.A. and Harbor, G. (1993) Lignin Modified Phenol-Formaldehyde Resin. US Patent 5202403.

[9] Zhao, L.W., Griggs, B.F., Chen, C.L. and Gratzl, J.S. (1994) Utilization of Softwood Kraft Lignin as Adhesive for the Manufacture of Reconstituted Wood. Journal of Wood Chemistry and Technology, 14, 127-145. http://dx.doi.org/10.1080/02773819408003090

[10] Sarkar, S. and Adhikari, B. (2000) Lignin-Modified Phenolic Resin: Synthesis Optimization, Adhesive Strength, and Thermal Stability. Journal of Adhesion Science and Technology, 14, 1179-1193. http://dx.doi.org/10.1163/156856100743167 
[11] Nada, A.A.M.A., Abou-Youssef, H. and El-Gohary, S.E.M. (2003) Phenol Formaldehyde Resin Modification with Lignin. Polymer-Plastics Technology and Engineering, 42, 689-699. http://dx.doi.org/10.1081/PPT-120023103

[12] Cetin, N.S. and Ozmen, N. (2003) Studies on Lignin-Based Adhesives for Particleboard Panels. Turkish Journal of Agriculture and Forestry, 27, 183-189.

[13] Khan, M.A. and Ashraf, S.M. (2005) Development and Characterization of a Lignin-Phenol-Formaldehyde Wood Adhesive Using Coffee Bean Shell. Journal of Adhesion Science and Technology, 19, 493-509. http://dx.doi.org/10.1163/1568561054352577

[14] El Mansouri, N.E. and Salvado, J. (2006) Structural Characterization of Technical Lignins for the Production of Adhesives: Application to Lignosulfonate, Kraft, Soda-Anthraquinone, Organosolv and Ethanol Process Lignins. Industrial Crops and Products, 24, 8-16. http://dx.doi.org/10.1016/j.indcrop.2005.10.002

[15] Matsushita, Y., Wada, S., Fukushima, K. and Yasuda, S. (2006) Surface Characteristics of Phenol-Formaldehyde-Lignin Resin Determined by Contact Angle Measurement and Inverse Gas Chromatography. Industrial Crops and Products, 23, 115-121. http://dx.doi.org/10.1016/j.indcrop.2005.04.004

[16] Wang, J., Chen, J.Z., Hou, Y. and Shao, C.Q. (2008) Research Progress of Yam Lignin-Phenolic Resin. China Adhesives, 9, 47-49.

[17] Cavdar, A.D., Kalaycioglu, H. and Hiziroglu, S. (2008) Some of the Properties of Oriented Strandboard Manufactured Using Kraft Lignin Phenolic Resin. Journal of Materials Processing Technology, 202, 559-563. http://dx.doi.org/10.1016/j.jmatprotec.2007.10.039

[18] Wang, M.C., Leitch, M. and Xu, C.B. (2009) Synthesis of Phenol-Formaldehyde Resol Resins Using Organosolv Pine Lignins. European Polymer Journal, 45, 3380-3388. http://dx.doi.org/10.1016/j.eurpolymj.2009.10.003

[19] Cranston, E.D. and Gray, D.G. (2006) Morphological and Optical Characterization of Polyelectrolyte Multilayers Incorporating Nanocrystalline Cellulose. Biomacromolecules, 7, 2522-2530. http://dx.doi.org/10.1021/bm0602886

[20] Lahiji, R.R., Xu, X., Reifenberger, R., Raman, A., Rudie, A. and Moon, R.J. (2010) Atomic Force Microscopy Characterization of Cellulose Nanocrystals. Langmuir, 26, 4480-4488. http://dx.doi.org/10.1021/la903111j

[21] Samir, M.A.S.A., Alloin, F., Sanchez, J.-Y. and Dufresne, A. (2004) Cellulose Nanocrystals Reinforced Poly(oxyethylene). Polymer, 45, 4149-4157. http://dx.doi.org/10.1016/j.polymer.2004.03.094

[22] Lahiji, R.R., Reifenberger, R., Raman, A., Rudie, A. and Moon, R.J. (2008) Characterization of Cellulose Nanocrystal Surfaces by SPM. NSTI-Nanotech, 2, 704-707.

[23] Sturcova, A., Davies, G.R. and Eichhorn, S.J. (2005) The Elastic Modulus and Stress-Transfer Properties of Tunicate Cellulose Whiskers. Biomacromolecules, 6, 1055-1061. http://dx.doi.org/10.1021/bm049291k

[24] Habibi, Y., Lucia, L.A. and Rojas, O.J. (2010) Cellulose Nanocrystals: Chemistry, Self-Assembly, and Applications. Chemical Review, 110, 3479-3500. http://dx.doi.org/10.1021/cr900339w

[25] Favier, V., Chanzy, H. and Cavaille, J.Y. (1995) Polymer Nanocomposites Reinforced by Cellulose Whiskers. Macromolecules, 28, 6365-6367. http://dx.doi.org/10.1021/ma00122a053

[26] Orts, W.J., Shey, J., Imam, S.H., Glenn, G.M., Buttman, M.E. and Revol, J.F. (2005) Application of Cellulose Microfibrils in Polymer Nanocomposites. Journal of Polymer and the Environment, 13, 301-306. http://dx.doi.org/10.1007/s10924-005-5514-3

[27] Noorani, S., Simonsen, J. and Atre, S. (2007) Nano-Enabled Micro-Technology: Polysulfone Nanocomposites Incorporating Cellulose Nanocrystals. Cellulose, 14, 577-584. http://dx.doi.org/10.1007/s10570-007-9119-y

[28] Dalmas, F., Chazeau, L., Cauthier, C., Cavaille, J.Y. and Dendievel, R. (2006) Large Deformation Mechanical Behavior of Flexible Nanofiber Filled Polymer Nanocomposites. Polymer, 47, 2802-2812. http://dx.doi.org/10.1016/j.polymer.2006.02.014

[29] Samir, M.A.S.A., Alloin, F., Paillet, M. and Dufresne, A. (2004) Tangling Effect in Fibrillated Cellulose Reinforced Nanocomposites. Macromolecules, 37, 4313-4316. http://dx.doi.org/10.1021/ma035939u

[30] Petersson, L., Kvien, I. and Oksman, K. (2007) Structure and Thermal Properties of Poly(lactic cid)/Cellulose Whiskers Nanocomposite Materials. Composites Science and Technology, 67, 2535-2544. http://dx.doi.org/10.1016/j.compscitech.2006.12.012

[31] Wang, N., Ding, E. and Cheng, R. (2007) Thermal Degradation Behaviors of Spherical Cellulose Nanocrystals with Sulfate Groups. Polymer, 48, 3486-3493. http://dx.doi.org/10.1016/j.polymer.2007.03.062

[32] Dufresne, A. and Vignon, M.R. (1998) Improvement of Starch Film Performances Using Cellulose Microfibrils. Macromolecules, 31, 2693-2696. http://dx.doi.org/10.1021/ma971532b

[33] Samir, M.A.S.A., Alloin, F., Sanchez, J.-Y., El Kissi, N. and Dufresne, A. (2004) Preparation of Cellulose Whiskers Reinforced Nanocomposites from an Organic Medium Suspension. Macromolecules, 37, 1386-1393.

http://dx.doi.org/10.1021/ma030532a 
[34] Kissinger, H.E. (1957) Reaction Kinetics in Differential Thermal Analysis. Analytical Chemistry, 29, $1702-1706$. http://dx.doi.org/10.1021/ac60131a045

[35] Ozawa, T.J. (1970) Kinetic Analysis of Derivative Curves in Thermal Analysis. Journal of Thermal Analysis and Calorimetry, 2, 301-324. http://dx.doi.org/10.1007/BF01911411

[36] He, G.B. and Yan, N. (2005) Effect of Wood on the Curing Behavior of Commercial Phenolic Resin Systems. Journal of Applied Polymer Science, 95, 185-192. http://dx.doi.org/10.1002/app.21115

[37] Lowry, R. (2008) Concepts and Applications of Inferential Statistics. Online Statistic Textbook. http://faculty.vassar.edu/lowry/webtext.html 